\title{
Mandado de Injunção: garantia constitucional à regulamentação dos tratados internacionais de direitos humanos fundamentais das pessoas com deficiência
}

\author{
Luiz Alberto David Araújo ${ }^{1}$ \\ Andréia Garcia Martin ${ }^{2}$ \\ Ana Catarina Piffer Gonçalves ${ }^{3}$
}

\begin{abstract}
Resumo: Pretende-se, com o presente trabalho, demonstrar que os direitos fundamentais que adentraram na Constituição por obra de tratados internacionais de direitos humanos, ante as renovadas determinações trazidas pela EC $45 / 04$, especificamente no que tange às pessoas com deficiência, possuem uma importância impar devendo ser obrigação dos Poderes de Estado, em defesa da supremacia da Constituição, garantir sua realização. Consignando-se que por conter nesses tratados de direitos humanos fundamentais dispositivos que necessitam de regulamentação, e sendo essa regulamentação irrefutavelmente desconsiderada, é perfeitamente cabível ao Poder Judiciário sua conformação para realizá-la, valendo-se, para tanto, do instrumento do mandado de injunção, para que sejam viabilizados os direitos das pessoas com deficiência.
\end{abstract}

Palavras-chave: Mandado de Injunção. Tratados Internacionais. Direitos Humanos Fundamentais. Pessoa com Deficiência.
Abstract: It is intended, with this present work, to demonstrate that, in the face of fundamental rights which entered the Constitution by the work of international human rights treaties, in view of the renewed regulations brought by EC $45 / 04$, specifically in regards to people with disabilities, the fundamental rights are extremely important and hence should be the obligation of the Powers of State, in defense of the supremacy of the Constitution, to guarantee its accomplishment. Noting that there are dispositives that need regulation, contained within this fundamental human rights treaty, which are being irrefutably disconsidered, their conformation to the Judiciary is perfectly appropriate in order to accomplish that, making use of the instrument of the writ of injunction, to this end, so that the rights of people with disabilities are made viable and amply protected.

Keywords: Writ/Order of injunction. International treaties. Fundamental human rights. People with disabilities.

Doutor em Direito Constitucional pela Pontifícia Universidade Católica de São Paulo. Professor titular de Direito Constitucional da Pontifícia Universidade Católica de São Paulo; Coordenador e docente do Curso de Pós-Graduação da Instituição Toledo de Ensino (ITE).E-mail: lada10@terra.com.br.

2 Advogada.Mestra em Direito Constitucional pela Instituição Toledo de Ensino (ITE). E-mail: draagmartin@hotmail.com.

3 Mestra em Direito Constitucional pela Instituição Toledo de Ensino (ITE).E-mail: catarinatucci@ yahoo.com.br.

Recebido em: 03/12/2010.

Revisado em: 08/01/2011.

Aprovado em: 14/02/2011. 


\section{Introdução}

O prelúdio com a preocupação e o resguardo da pessoa humana tornou-se mais marcante, em países do ocidente, principalmente após a segunda guerra, que por obra da Declaração Universal dos Direitos Humanos de 1948 generalizou a consignação de direitos, permeando-os de uma tutela axiologicamente condicionada ao próprio ser humano.

Ademais, com a evolução e complexificação da sociedade ampliouse a necessidade de prover de direitos certas camadas da população historicamente excluídas por não se enquadrarem nos padrões da normalida$d e$, isso se deu principalmente com as pessoas portadoras de deficiência.

Em terra brasilis, pode-se dizer que foi somente a partir da Constituição Federal de 1988, com a inauguração do processo de redemocratização do Estado, que se iniciou uma escalada no sentido de procurar tutelar de forma ampla esse grupo de pessoas, vez que, além de suplantada a mera declaração de direitos, foi tomada como núcleo máximo de toda a engrenagem jurídico-constitucional da sociedade a pessoa humana, dignamente considerada.

Nessa vereda, ante a crescente antropologização da tutela jurídica, pretende-se com o presente fomentar uma melhor compreensão da garantia constitucional do mandado de injunção conjecturada na Carta Maior - e que ainda, nos dias atuais, não vem sendo utilizada como deveria -, como instrumento imprescindível para a defesa dos direitos das pessoas com deficiência.

Ademais, apesar do mandado de injunção ser um dos institutos mais significativos para assegurar os direitos fundamentais sua utilização continua restrita, devido a dois fatores: de um lado, pelo excessivo apego à ausência de instrumento formal que lhe dê propriamente aplicabilidade, voltado a uma interpretação ultrarrestritiva do Texto Constitucional; e, por outro, ante a inércia dos operadores do direito em vislumbrarem tal garantia como um verdadeiro acesso a direitos fundamentais.

Assim, em que pesem alguns desses direitos sejam dependentes de regulamentação para surtirem efeito prático - quer decorrentes da Cons- 
tituição ou de instrumentos internacionais -, por ocasião da Emenda Constitucional 45/04, tem-se que diante de tratados de direitos humanos ratificados pelo Brasil, que igualmente contemplem a necessidade de regulamentação, insurge-se premente a ampla utilização deste instituto.

A Constituição, especificamente nos casos dos direitos fundamentais, voltados às pessoas com deficiência, prevê que norma ulterior regulamente os direitos internacionalmente traçados por tratado, no qual o Brasil é signatário, para esse grupo de pessoas.

Atém-se o presente estudo à constatação da necessidade e eficiência do mandado de injunção, almejando que este seja cada vez mais utilizado a fim de que possam ser usufruídos os resultados antes desejados pela Lei Maior. Propondo, ante ao novo horizonte das decisões do Supremo Tribunal Federal, a possibilidade do mandado de injunção viabilizar o teor dos tratados internacionais sobre direitos humanos das pessoas com deficiência.

\section{Dos Direitos Humanos Fundamentais}

Os direitos fundamentais, que se conhece na atualidade, decorrem de uma locupletação contínua no percorrer da história desde a sua primeira aparição com a implantação do Estado de Direito no século XVIII, que sob as vestes liberais propugnava em superar os excessos dos monarcas, sob o fulcro de um insurgente movimento de separação de poderes.

A implantação deste Estado de Direito decorreu, ainda que com interesses diversos, de dois marcos revolucionários que contribuíram significativamente para a queda do absolutismo vigente à época, bem como para o estabelecimento e perpetuação de direitos em Cartas de intenções, abrolhando, assim, os primeiros documentos políticos dos Estados. Esses movimentos foram: a Revolução Americana de 1776 - que almejava a independência e a insurgência de um governo democrático - e a Revolução Francesa de 1789 - fulcrada no respeito à liberdade e à igualdade das pessoas.

Nesse Estado de Direito de índole Liberal surgem os direitos individuais, conhecidos como direitos fundamentais de primeira geração, cujo objetivo era defender o cidadão, suplantando os incessantes desmandos 
do absolutismo que reinava à época. É marcado pelo signo da liberdade dos indivíduos diante do Estado por meio da não intervenção, apoiandose na técnica da separação de poderes, vez que incumbiriam aos órgãos estatais, com funções diferenciadas, se limitarem mutuamente.

Os direitos individuais, entretanto, beneficiavam apenas a pessoa individualmente considerada, não conjecturando os anseios da sociedade. Surge assim, os direitos de segunda geração, que ao lado dos primeiros, esquadrinham direitos sociais, ensejando a necessidade de o Estado intervir nas relações imbricadas no interior da sociedade como forma de garantir a realização da justiça social, diminuindo as desigualdades econômicas e sociais, além de se tornar um autêntico prestador das necessidades de seus membros. Desabrocha-se o Estado Social que, em virtude do alicerce antropológico dos direitos fundamentais não ser tão só "[...] o 'homem individual', mas também o homem inserido em relações sócio-políticas e socioeconômicas e em grupos de várias naturezas, com funções sociais diferenciadas [...]" (CANOTILHO; MOREIRA, 2007, p. 112), torna inoperante as aspirações estatais liberais, premendo-se por um Estado proativo ante as necessidades de seus membros.

Posteriormente, pelo fato de ser inerente a tais direitos a característica da historicidade houve uma ampliação desses, dando azo ao surgimento dos direitos de terceira geração, compreendidos os direitos difusos e coletivos e não apenas o grupo social em que cada indivíduo estava inserido, ou seja, de toda coletividade. Os direitos de quarta geração, referem-se à globalização, tendo assim, como nos direitos de terceira geração, por titulares os seres humanos, no sentido de povo, nação.

Nesse diapasão, já em meados do século XX o Estado de Direito é adjetivado de Constitucional se aperfeiçoando por meio da adesão das concepções do Estado de Direito e Democrático, que se embasando sob tais alicerces garantem, em seu maior grau, os direitos fundamentais. Diferencia-se do simples Estado de Direito de cunho Liberal ou mesmo Social, pois conjuga direitos humanos em todas as dimensões, ratificando, dessa forma, uma postura positiva do Estado, desejando-se muito mais que a mera declaração de direitos. Sob o escólio de Antonio-Enrique Pérez Luño (1995, p. 19) elucubra-se que: 
Existe um estreito nexo de interdependência genético e funcional entre o Estado de Direito e os direitos fundamentais, uma vez que o Estado de Direito exige e implica, para sê-lo, a garantia dos direitos fundamentais, ao passo que estes exigem e implicam, para sua realização, o reconhecimento e a garantia do Estado de Direito. (tradução livre do autor).

Dessa forma, vislumbrou-se que, ante os resultados trágicos acarretados pela Segunda Guerra Mundial elevou-se a preocupação com a pessoa humana, passando-se a albergar um feixe de direitos acoplados em si de maneira inédita, vez que combinavam os direitos advindos dos ideais liberais com direitos consignados no Estado Social, conjecturando-se a concepção contemporânea de direitos humanos, que ensejam uma edificação de caráter emancipatório direcionado à tutela da dignidade humana, esta conjuntura se deu principalmente no ocidente em países que adotaram o capitalismo. Em nossa realidade, apesar das Cartas anteriores terem trazido alguma preocupação, foi somente na Constituição Federal de 1988, com a retomada da democracia, que a dignidade humana ganhou vultos de princípio e passou a nortear toda a estrutura de nosso ordenamento jurídico.

Ao se deblaterar sobre a adoção entre as terminologias direitos humanos ou fundamentais, constata-se que não é tarefa simples conceituálos, tão pouco, falar do alcance desses direitos. Assim, dizer que existem direitos fundamentais significa que há certas situações reconhecidas pelo ordenamento jurídico como valiosas, assegurando a Constituição um nível reforçado de proteção, ou seja, muito superior ao que se outorga a outras situações de legítima prerrogativa individual. Essa proteção se coloca acima das atuações dos órgãos judiciais, administrativos, frente ao Poder Legislativo e ao Poder constituinte derivado (CHINCHILLA HERRERA, 1999, p. 3), "[...] além de ser objeto de resguardo, igualmente, pelo Poder Judiciário".

Ademais, é necessário ressaltar que a própria Constituição Federal não uniformizou sistematicamente um termo ao se referir aos direitos fundamentais, contudo, não deixou dúvidas de que se tratava de direitos 
dotados de fundamentalidade 4 . Ora, essa falta de consenso quanto à locução referida reflete a heterogeneidade dos representantes da sociedade que integraram a elaboração da Carta Constitucional por ocasião da Assembleia Nacional Constituinte de 1987.

Nesse sentido, para uma conjectura mais embasada sobre os direitos humanos, que conforme assevera Flávia Piovesan (1999) assinalam uma multiplicidade de concepções, deve-se, outrossim, considerar algumas características que têm o condão de distingui-los, como: a historicidade, a universalidade e indivisibilidade.

Pela historicidade, deduz-se sua adoção insurgida com a Declaração Universal de 1948 e reafirmada pela Declaração de Direitos Humanos de Viena de 1993. Afirma-se ainda universal, “[...] porque a condição de pessoa há de ser o requisito único para a titularidade de direitos, afastada qualquer outra condição [...]"; bem como, indivisível, “[...] porque os direitos civis e políticos hão de ser somados aos direitos sociais, econômicos e culturais, já que não há verdadeira liberdade sem igualdade e nem tampouco há verdadeira igualdade sem liberdade [...]" (PIOVESAN, 1999, p. 92).

Em complemento, há de se considerar o entendimento de Joaquim Herrera Flores (2009, p. 43) ao afirmar que o conceito de direitos humanos inicialmente "[...] surgiu em um contexto particular (Ocidente) difundiu-se por todo o globo como se fosse o mínimo ético necessário para se lutar pela dignidade". Porém, seu surgimento não se processou de maneira espontânea, como se decorresse da própria evolução da sociedade, pelo contrário, foi marcado por muitas lutas e conflitos, depreendendo-se que

[...] são essas lutas que, na realidade permitem que tal conceito se "universalize" como base ética e jurídica de toda prática social voltada a criar e garantir instrumentos úteis na hora de poder ascender

\footnotetext{
4 A Constituição Federal utilizou-se de termos como: "prevalência dos direitos humanos", artigo 4"; "direitos e liberdades fundamentais", artigo 5', XLI; "direitos e garantias fundamentais", artigo $5^{\circ}, \S 1^{\circ}$; "direitos e deveres individuais e coletivos", Capítulo I; "direitos fundamentais da pessoa humana", artigo 17; "direitos da pessoa humana", artigo 34, VII, b; e "direitos individuais", nos artigos 145, § 1; 68, II; e 85, III.
} 
aos bens materiais e imateriais exigíveis para se viver com dignidade (HERRERA FLORES, 2009, p. 43).

Nesse diapasão, convém destacar que, em apertada síntese, “direitos humanos" seriam os direitos consagrados internacionalmente, enquanto os "direitos fundamentais" seriam aqueles firmados em cada país, por suas respectivas Constituições. Porém, ainda assim, conformam-se em facetas equidistantes da mesma moeda, ensejando a mesma gama de direitos tomados em âmbitos diferentes, ou seja, os direitos humanos constitucionalizados detêm nominação de direitos fundamentais, possuidores, ainda, da humanidade que lhes são inerentes.

A deferência especificamente sobre os direitos fundamentais, conforme cotejado pelo Supremo Tribunal Federal, observe-se o voto do Ministro Marco Aurélio Mello no julgamento do HC 82.424/RS, que definiu os sistemas de direitos fundamentais como o cerne da Constituição, caracterizando-os como os valores norteadores de todo ordenamento jurídico interno. Depreende-se, dessa forma, que os Ministros do STF acabaram por estabelecer o alicerce jurídico e axiológico da interpretação dos direitos fundamentais constantes da Carta Constitucional. Transcreve-se o teor do voto do citado Ministro:

A Constituição de 1988 representou um divisor de águas entre o antigo regime totalitário e um período de redemocratização do País, marcando dessa forma, uma época que tem como modelo de atuação do Estado o respeito incondicional aos direitos fundamentais. Por isso mesmo, o sistema constitucional dos direitos fundamentais, previsto no art. $5^{\circ}$ da Carta, com os eventuais acréscimos do $\S 2^{\circ}$, reflete, em rigor e em larga medida, a própria essência da Constituição e a retomada do processo de democratização e da garantia do cidadão contra abusos e arbitrariedades no exercício do Poder Público. Os direitos fundamentais são hoje verdadeiros princípios estruturantes da organização e do funcionamento do Estado, valores objetivos que servem como norte da atuação estatal em seus diferentes níveis: no Legislativo, formam um catálogo de princípios e garantias que informam e direcionam toda atividade de criação das normas de nosso ordenamento jurídico e de concretização dos 
preceitos constitucionais; no Executivo, mostram-se como verdadeiros limites ao exercício do poder administrativo, servindo como trincheiras de proteção da liberdade do cidadão; e, no Judiciário, refletem a base e o fundamento necessário da compreensão e interpretação de nossas normas - efeito interpretativo -, evitando que a atividade jurisdicional se transforme em medidas discricionárias ou providências ilegítimas de opções políticas pautadas em escolhas pessoais de juízes (BRASIL, 2004, s./p.).

Assim, optou-se, no estudo em questão, por adotar a denominação de direitos humanos fundamentais, já que se tratam de direitos reconhecidos internacionalmente e que foram acolhidos pela ordem jurídico-constitucional interna, detendo uma fundamentalidade ínsita por serem arquitetados, em sua essência, axiologicamente na pessoa humana. Assim, enseja-se que a ratificação destes pelo Brasil, em que pese não estarem consignados explicitamente no Texto Constitucional, são decorrentes de seus objetivos e regime adotados por nosso Estado.

Ademais, há que se considerar que as determinações insertas do artigo $4^{\circ}$ da Constituição, em que consta uma forma de participação direta do país em prol desses direitos que estão registrados nas alianças estabelecidas com outras nações, a fim de propiciar a cooperação dos países signatários, como garantia do progresso da humanidade. Regendo-se, especialmente, por um princípio de prevalência dos direitos humanos (inciso II, artigo $4^{\circ}$ ), ensejo que externaliza a preocupação dos Constituintes em dar respaldo aos direitos da pessoa humana e de assegurar a democracia que se instaurava. Nesse sentido, afiança Celso Lafer $(2005$, p. 14) que:

No art. $4^{\circ}$, a clara nota identificadora da passagem do regime autoritário para o Estado democrático de direito é o princípio que assevera a prevalência dos direitos humanos (art. $4^{\circ}$, II). Este princípio afirma uma visão do mundo - que permeia a Constituição de 1988 - na qual o exercício do poder não pode se limitar à perspectiva dos governantes, mas deve incorporar-se à perspectiva da cidadania.

A necessidade da incorporação à perspectiva da cidadania vislumbra-se na íntima relação que ela tem frente aos direitos humanos, numa 
remodelagem em que se sustenta toda uma arquitetura de índole ético-política-democrática sob a qual pairam todos os atores estatais. Nesse patamar têm-se a universalização da cidadania, que em sua forma mais ampla, proporciona a todos os cidadãos o acesso a direitos sem os quais a própria humanidade estaria prejudicada, ou seja, através desse princípio busca-se reafirmar a insofismável consideração aos direitos humanos pelos Poderes de Estado.

Entretanto, cabe ressaltar que importa apenas a realização desses direitos, tendo pouca importância os termos utilizados, ou seja, o que interessa é a concretização do conteúdo deles. Nesse sentido, convém se asseverar que:

Constitui o conteúdo essencial de um direito subjetivo aquelas faculdades ou possibilidades de atuação necessária para que o direito seja reconhecido como pertencente ao tipo descrito. Todo o referido ao momento histórico de que em cada caso se trate e das condições inerentes às sociedades democráticas, quanto se trate de direitos constitucionais. O segundo caminho possível para definir o conteúdo essencial do direito consiste em tratar de buscar o que uma importante tradição tem chamado de interesses juridicamente protegidos como núcleo e medula dos direitos subjetivos.

Se pode então falar de uma essencialidade do conteúdo do direito para fazer referência àquela parte do conteúdo do direito que é absolutamente necessária para que os interesses juridicamente protegidos, que dão vida ao direito, resultem em real, concreta e efetivamente protegidos. (MARTINEZ PULJATE, 1997, p. 63, tradução livre do autor). ${ }^{5}$

5 Texto original: "Constituyen el contenido esencial de um derecho subjetivo aquellas facultades o posibilidades de actuación necessárias para que el derecho sea recognoscible como perteneciente as tipo descrito... Todo ello referido al momento histórico de que em cada caso se trate y a las condiciones inherentes a las sociedades democráticas, cuando se trate de derechos constictucionales. El segundo camino posible para definir el contenido esencial de derecho consiste em tratar de buscar lo que uma importante tradición há llamado los interesses jurídicamente protegidos como núcleo y medula de los derechos subjetivos. Se puede entonces hablar de una esencialidad del contenido del derecho para hacer referencia a aquella parte del contenido del derecho quees absolutamente necessária para que los interesses juridicamente protegibles, que dan vida al derecho, resulten real, concreta y efectivamente protegidos". 
Observa-se que a preocupação das Constituições sempre esteve voltada à grandiosidade do significado que tais direitos representam para a humanidade, merecendo destaque pela importância que possuem no contexto social para o ser humano. Com efeito, convém ressaltar que a abordagem deste estudo não recairá sobre a previsão, mas sobre a proteção e o cumprimento dos direitos fundamentais, principalmente, das pessoas com deficiência.

\section{A Sociedade Frente à Pessoa com Deficiência}

Desde os primórdios da humanidade as pessoas com deficiência são açoitadas com mastodônticas e variadas formas de exclusão e segregação, negando a eles até mesmo a qualidade de seres humanos.

Até por volta da década de 60 do século passado se tem notícia que alguns países da Europa ainda se utilizavam de uma limpeza genética, advinda das práticas eugênicas dos nazistas, sob as pessoas com deficiência. Registre-se que, essas eram largamente aplicadas no afã de que: ao se exterminar esses indivíduos estar-se-ia escondendo suas verdadeiras raízes criando uma purificação, que atualmente provou-se inalcançável (BYDLOWSKI, 1997). Ora, nega-se a própria humanidade desse grupo, ignorando a diversidade humana e a diferença que são ínsitas em cada indivíduo.

Bem se expressa Roberto Francisco Daniel (2003, p. 559) ao afirmar que "[...] cada pessoa humana cria através de suas decisões e ações éticas uma única e insubstituível realidade e conquista uma dignidade inédita".

É por esse foco que se enveredará este estudo, constatando que é a partir da conscientização dos indivíduos e consequente atuação da sociedade que o Estado será compelido a atuar positivamente.

A sociedade é a grande propulsora dos avanços legislativos com relação às pessoas com deficiência, tendo o Estado por legítimo protetor e, sobretudo, o elemento adequado para se exigir a efetivação dos direitos fundamentais, ou seja, suplanta-se a mera tutela individual dos direitos 
das pessoas com deficiência, pois, em que pese pertença a cada um isoladamente, são direitos afeitos a todo esse segmento social.

Mesmo sendo as pessoas com deficiência conformadas como diferentes da normalidade, no âmago social, essas diferenças tornam-se marginalizantes, impregnadas de preconceito - que impossibilitam a aceitabilidade social - e de intolerância e descriminação - que impedem sua inclusão.

Tal categoria de pessoas nem sempre foi vista com bons olhos pela sociedade. Não se tem claro os motivos, talvez pela falta de conhecimento, talvez pela falta de sensibilidade, o fato é que por longo tempo foram segregadas do convívio social, por puro preconceito. Sendo, por consequência, denegados seus direitos ínsitos. Nesse sentido, aduz Cláudia Werneck que:

É difícil mesmo escalar o muro do preconceito (é nele que aprendemos a subir desde criança) e, ao descer, pular para o outro lado, o lado do novo, do desconhecido, da informação que amedronta, e até parece piegas de tão libertadora que é. (WERNECK, 1999, p. 59).

Há relatos de discriminação das pessoas pertencentes a esse grupo social até mesmo na própria escritura sagrada, quando eram excluídas da vocação sacerdotal as pessoas que apresentassem qualquer tipo de deficiência. (BÍBLIA SAGRADA, Levítico, Cap. 21, vers. 18-21).

Ora, a superação do preconceito torna-se palatável ante a escalada em direção à tolerância. Porém, com o intuito de se esclarecer o que compreenderia a tolerância, há que se ressaltar que esta implica um embate entre dois princípios da moral: da consciência e, do respeito ou da benevolência. "Pelo primeiro, o sujeito coloca sua verdade íntima, acima de tudo; pelo segundo, toma-se um sentimento de consideração e compaixão para com o outro" (BOBBIO, 1992, p. 208). Dessa forma, a tolerância refletiria um sentimento de solidariedade para com os grupos da sociedade que sofrem com o preconceito e a intolerância daqueles que não enxergam os diferentes como detentores de toda a gama de direitos, retirandolhes até mesmo a própria humanidade. 
Nesse sentido, a Unesco em sua Declaração de princípios sobre a tolerância assevera em seu artigo $1^{\circ}$ que "[...] a tolerância é, antes de tudo, uma atitude ativa, fundada no conhecimento dos direitos universais da pessoa humana e das liberdades fundamentais do outro". Assim, “[...] em nenhum caso a tolerância poderia ser invocada para justificar lesões a esses valores fundamentais. A tolerância deve ser praticada pelos indivíduos, pelos grupos e pelo Estado [...] (1.3). A tolerância é o sustentáculo dos direitos humanos, do pluralismo [...]" (UNESCO, 1995, art. 1º, tradução livre do autor).

Entretanto, a tolerância “[...] não é uma concessão, condescendência, indulgência [...] nem (significa) renunciar às próprias convicções, nem fazer concessões a respeito [...]”' (UNESCO, 1995, art. 1º).

Destaque-se o escólio trazido por Norberto Bobbio

[...] não é apenas a adoção de um método de convivência preferível a outro [...] o tolerante não é cético, porque crê em sua verdade. Tampouco é indiferente, porque inspira sua ação num dever absoluto, como é o caso de respeitar a liberdade do outro (BOBBIO, 1992 p. 209).

A tolerância é o consenso mesmo na diferença, é a harmonização das diversidades humanas fundada no respeito, na valorização e no assentimento de tais diversidades. Não se baliza simplesmente num dever ético, é este, antes de tudo, de índole social, política e jurídica, vez que se busca como reflexo máximo a tolerância dos Poderes de Estado para se alcançar a igualdade em seu patamar social.

Com efeito, para que haja a inclusão das pessoas com deficiência no seio da sociedade, é preciso, antes de qualquer coisa, que ocorra aceitação dentro de cada indivíduo (Princípio da Tolerância) nela inserido. Sendo indispensável que aconteça uma transformação de valores, em que exista a crescente e continua preocupação com o todo.

Passadas as elucubrações exaradas acima convém partirmos para a conceituação da pessoa com deficiência. Entretanto, não é tarefa simples definir quem são as pessoas com deficiência. Segundo entende-se 
“[...] deficiência há de ser entendida levando-se em conta o grau de dificuldade para a integração social e não apenas a constatação de uma falha sensorial ou motora, por exemplo" (ARAUJO, 2001, p. 13). Ou ainda:

O que define a pessoa portadora de deficiência não é falta de um membro nem a visão ou audição reduzidas. O que caracteriza a pessoa portadora de deficiência é a dificuldade de se relacionar, de se integrar na sociedade. O grau de dificuldade para a integração social é que definirá quem é ou não portador de deficiência (ARAUJO, 2001, p. 13).

Com efeito, o deficiente não conjecturaria simplesmente uma anomalia vislumbrada a olho nu, já que muitas pessoas ditas normais tem extrema dificuldade de integrarem-se socialmente, apesar deste conceito ser deveras amplificado, configura-se como o mais apto a conformar uma atitude inclusivista a essas pessoas, dada a heterogeneidade desse grupo, além de representar um grande passo à efetiva tutela desse segmento social.

No entanto, o maior problema não é conceituar a pessoa com deficiência, e, sim combater a discriminação e intolerância que as assolam diuturnamente. Enquanto a humanidade não os enxergar como pessoas dignas de direitos e potencialidades, independentemente de sua condição física ou mental, para muitos, os deficientes vão continuar sendo a representação da pessoa (ou coisa) que importuna e é justamente esta concepção que o direito deve apoitar, encravando alicerces em uma profícua e contínua tutela das pessoas com deficiência, principalmente ante a agigantada consideração que estes galgaram na ordem jurídica internacional.

\subsection{A Pessoa com Deficiência sob a Perspectiva Constitucional dos Direitos Fundamentais: a tutela dos tratados internacionais de direitos humanos}

Indubitavelmente, às pessoas com deficiência são inerentes os direitos pertencentes a todos os demais indivíduos do grupo social. Entretanto, por pesar sobre elas um vigoroso fardo de preconceito, intolerância e ignorância, o compromisso constitucional de se instaurar uma sociedade 
solidária permeada pela redução das desigualdades e da marginalização é praticamente lhes é denegado, sendo inclusive recorrente a total inconcretude dos direitos a esse segmento, como se não fossem dignos de detê-los, formando um quadro de total descaso e falta de solidariedade social do grupo.

Neste ínterim, constata-se que, antes da Constituição Federal tratar especificamente dos direitos fundamentais, o artigo $3^{\circ}$ já trazia as diretrizes da inclusão e solidariedade social, estabelecendo os parâmetros em que o Estado deve se fundar para garantir a existência de uma sociedade solidária, capaz de reduzir as desigualdades e proibir qualquer espécie de preconceito ou discriminação.

Constituem objetivos fundamentais da República Federativa do Brasil:

I - construir uma sociedade livre, justa e solidária;

II - garantir o desenvolvimento nacional;

III - erradicar a pobreza a marginalização e reduzir as desigualdades sociais e regionais;

IV - promover o bem de todos, sem preconceitos de origem, raça, sexo, cor, idade e quaisquer outras formas de discriminação. (BRASIL, 1988, art. $3^{\circ}$ ).

Interpretando o artigo no objetivo de sua criação, nota-se que o intuito do legislador constituinte se estende às pessoas com deficiência quando coibiu qualquer forma de exclusão, determinando que o Estado tomasse as medidas cabíveis para abolir todos os tipos de discriminação e marginalização.

Além de tratar dos direitos e garantias fundamentais de forma genérica, o legislador abordou a inclusão social da pessoa com deficiência, editando normas específicas na tentativa de ampliar a proteção de seus direitos. Todavia, para desenvolver esta gama de tarefas, incumbiu a legislação infraconstitucional, de dar continuidade na regulamentação de leis, a fim de complementar o que fosse necessário. 
Nesse sentido, a Lei n. 7.853, de 24 de outubro de 1989, surgiu com intuito de dar maior proteção às pessoas portadoras de deficiência sendo protegidas pela Lei da Ação Civil Pública. Porém, esta lei não definiu claramente quem seriam as pessoas com deficiência. Pois, embora traçasse várias ações a serem cumpridas em prol da tutela destas pessoas, não havendo a definição de tais deficiências, o instrumento se tornava impotente.

Já o Decreto n. 3.298, de 20 de dezembro de 1999, tentou definir quem era pessoa com deficiência. Contudo, por lhe faltar clareza, acabou por deixar diversas modalidades de deficiência desamparadas.

Frente a esse quadro de total descompasso do juridicamente tutelado e a realidade que se desvelava, eis que surge a Convenção sobre os Direitos das Pessoas com Deficiência, ratificada pelo Brasil no dia 10 de julho de 2008, determinando em seu artigo $1^{\circ}$ que:

Pessoas com deficiência são aquelas que têm impedimentos de longo prazo de natureza física, mental, intelectual ou sensorial, os quais, em interação com diversas barreiras, podem obstruir sua participação plena e efetiva na sociedade em igualdades de condições com as demais pessoas (BRASIL, 2008, art. $1^{\circ}$ ).

Apesar dos distintos campos que se delimitou esta definição, induzse que a incapacidade existe em razão da relação entre as pessoas com deficiência e o seu ambiente, incidindo deveras perniciosa quando essas pessoas se deparam com obstáculos culturais, físicos ou sociais que tornam impraticável o seu acesso aos diversos sistemas da sociedade que se encontram à disposição dos demais cidadãos. Assim sendo, em apertada síntese, a incapacidade é a perda ou a limitação das oportunidades de participar da vida em igualdade de condições com os demais.

Dentro desse panorama, a deficiência representaria um espectro hipercomplexificado de carências ou impossibilidades humanas, recrudescendo, por consequência, em infinitas possibilidades de tutela dos direitos das pessoas que se encontrem nessa situação, quer definitiva ou transitoriamente.

Dessa forma, 
[...] sem uma interpretação mais efetiva, menos restritiva do Texto Constitucional não conseguiremos cumprir os mandamentos de efetividade constantes na Constituição Federal de 1988 [...] (ARAUJO, 2005, p. 649).

O que cumpre aos operadores do direito é dar continuidade ao objetivo do legislador constituinte originário e permitir que estes direitos sejam satisfeitos em sua maior plenitude. Inobstante possa se contar com outras possibilidades de direitos fundamentais aqueles decorrentes dos tratados que o Brasil é signatário.

Igualmente, caberia ao Judiciário, realizar uma interpretação conforme a Constituição, de modo a propiciar uma melhor compreensão do tema, diante de situações complexas e possibilitar que fosse reconhecida constitucionalmente a ampliação de tal conceito, atribuindo tanto ao próprio Judiciário como aos Poderes Públicos meios de efetivar, de forma abrangente, os direitos das pessoas com deficiência.

Tendo em mente a importância deste direito atingir-se-á as formas desenvolvidas para exercitá-lo, já que a Constituição além de prevê-lo, determinou meios aptos para seu desenvolvimento. Assim, o próximo passo do estudo será analisar o novo paradigma instaurado pela Emenda Constitucional 45/04 que equipara os tratados internacionais de direitos humanos à norma constitucional quando inseridas com procedimento Emenda Constitucional, bem como o instrumento do Mandado de Injunção como um importante mecanismo constitucional que possibilitará a realização dos direitos fundamentais das pessoas com deficiência.

\section{O Novo Paradigma Instaurado com A EC n. 45/04: da equi- paração dos tratados internacionais sobre direitos humanos à "Norma Constitucional"}

Com a Emenda Constitucional n. 45 de 2004 instituiu-se, na ordem interna $^{6}$, a possibilidade dos tratados assinados pelo Brasil sob as matérias

\footnotetext{
6 Nas palavras de Luís Roberto Barroso, “[...] o tema do conflito entre as normas internacionais e a ordem interna evoca duas grandes correntes doutrinárias que disputam o melhor equacionamento da questão: o dualismo, pregado no âmbito internacional por Triepel
} 
que veiculassem direitos humanos, e que fossem devidamente referendados pelas Casas do Congresso (com quorum qualificado) e ratificado pelo Presidente da República, o status equivalente à emenda constitucional.

A redação do Texto Constitucional anterior à emenda assinalava que:

[...] os direitos e garantias expressos nesta Constituição não excluem outros decorrentes do regime e dos princípios por ela adotados, ou dos tratados internacionais em que a República Federativa seja parte (BRASIL, 1988, art. $5^{\circ}, \S 2^{\circ}$ ).

Esta era a consideração da fundamentalidade afeita às normas decorrentes dos tratados nos quais o Brasil fosse signatário. Entretanto, detinham tão só uma fundamentalidade material, já que conjecturavam apenas força de lei ordinária, ou como eram nominadas, pela melhor doutrina, normas supralegais.

Nesta senda, pode-se elucubrar que nossa Corte Constitucional $^{7}$ perfilhou um tipo de monismo mitigado ou moderado. ${ }^{8}$ De acordo com o que assinala Luís Roberto Barroso (2004, p. 19), a

e Anzilotti e seguido no Brasil por Amílcar de Castro, e o monismo, concepção desenvolvida por Hans Kelsen e seguida no Brasil pela maior parte da doutrina, inclusive Valladão, Tenório, Celso D. de Albuquerque Mello e Marotta Rangel". (BARROSO, 2004, p. 15). E ainda, continua, asseverando que "[...] a doutrina dualista, também entendida como paralelismo do Direito público, considera o Direito Internacional e o Direito interno como dois sistemas jurídicos igualmente válidos, todavia distintos, independentes e separados. Por sua vez, as concepções monistas defendem o princípio da unidade entre Direito Internacional e Direito Interno, como um bloco único de regras jurídicas, integradas num vasto sistema normativo. Não há duas ordens jurídicas estanques - como afirmam os dualistas -, cada uma válida exclusivamente na sua órbita, mas um só mundo jurídico, coordenado, eficaz, regendo o conjunto das atividades sociais dos indivíduos e das coletividades" (BARROSO, 2004, p. 17). 7 Em que pese o Supremo Tribunal Federal tenha como função precípua a jurisdição constitucional, a adoção dessa expressão, como sinônima de STF, este não pode ser considerado originariamente como uma verdadeira Corte Constitucional na concepção técnica da expressão, vez que, além de órgão exerce uma função de Jurisdição de $3^{\circ}$ grau do Poder Judiciário brasileiro, a teor do artigo 102, inciso III, da Lei Maior, bem como não se formou e se instituiu nos mesmos moldes dos países que adotam e seguem à risca os redutos dessa expressão.

8 "Vislumbra-se na jurisprudência do STF, a existência de uma igualização entre a norma jurídica de produção doméstica e a norma jurídica nacional oriunda de determinação internacional" (VELOSO, 2004, p. 43). 
[...] orientação da mais alta Corte é a do monismo moderado, em que tratado se incorpora ao direito interno no mesmo nível hierárquico da lei ordinária, sujeitando-se ao princípio consolidado.

Nesse sentido, convêm asseverarmos a respeito do Pacto de San José da Costa Rica ou também chamado de Convenção America de Direitos Humanos (CADH) que, igualmente, concedeu aos Tratados Internacionais de Direitos Humanos, no ordenamento interno, o status de norma supralegal, o que nos permite afirmar que na pirâmide hierárquica das normas, estão abaixo da Constituição Federal, contudo, acima das demais Leis e atos normativos do sistema.

Ademais, importante também abordarmos a nova perspectiva assumida pelo país com relação à prisão civil por dívida ao descumprimento indesculpável de prestação alimentícia, tendo em vista a decisão do STF ao julgar o HC n. 87.585/TO. Da decisão proferida nesse julgamento concluiu-se que, independente da celeuma que girava em torno do status que assume os tratados e convenções internacionais de direitos humanos dentro do ordenamento brasileiro, não há mais respaldo legal para prisão civil de depositário infiel, cabendo a ela somente por dívida ao descumprimento inescusável de prestação alimentícia.

A mesma orientação foi seguida com relação ao RE n. 349.703 e RE n. 466.443. Contudo, necessário observar que no voto do Ministro Celso de Mello há a defesa da tese de que os tratados que versem sobre direitos humanos subscritos pelo Brasil teriam status constitucional e não supralegal, como verificado anteriormente. ${ }^{9}$

9 "No ponto, destacou a existência de três distintas situações relativas a esses tratados: 1) os tratados celebrados pelo Brasil (ou aos quais ele aderiu), e regularmente incorporados à ordem interna, em momento anterior ao da promulgação da $\mathrm{CF} / 88$, revestir-se-iam de índole constitucional, haja vista que formalmente recebidos nessa condição pelo $\S 2^{\circ}$ do art. $5^{\circ}$ da CF; 2) os que vierem a ser celebrados por nosso País (ou aos quais ele venha a aderir) em data posterior à da promulgação da EC 45/2004, para terem natureza constitucional, deverão observar o iter procedimental do $\S 3^{\circ}$ do art. $5^{\circ}$ da $\mathrm{CF} ; 3$ ) aqueles celebrados pelo Brasil (ou aos quais nosso País aderiu) entre a promulgação da $\mathrm{CF} / 88$ e a superveniência da EC 45/2004, assumiriam caráter materialmente constitucional, porque essa hierarquia jurídica teria sido transmitida por efeito de sua inclusão no bloco de constitucionalidade. RE 466343/SP, rel. Min. Cezar Peluso, 12.3.2008. (RE- 466.343)”. 
Conclui-se, assim, que se o tratado é incorporado ao ordenamento jurídico interno com a mesma votação de Emenda Constitucional, ou seja, nos moldes do $\S 3^{\circ}$ do artigo $5^{\circ}$ da Excelsa Carta, o mesmo derroga disposições constitucionais que o contrariam. Se o documento internacional ingressa em nosso sistema com status de norma supralegal, e desta forma, cumpre-nos ressalvar como norma infraconstitucional, não exclui os direitos e nem é revogado pela Carta Maior, pois o $\S 2^{\circ}$ do artigo $5^{\circ}$ desse dispositivo cominado com o artigo 29 do Pacto de San José da Costa Rica observa a regra de interpretação pro homini, qual seja, a de prevalecer a norma que mais amparo garanta aos direitos da pessoa humana.

Em tempo, retomando o assunto a respeito do fenômeno do monismo moderado, convém asseverar que ele era incisivo sobre assuntos que envolviam normas oriundas da ordem internacional que conflitavam com as normas internas, contudo, com o advento da Emenda Constitucional n. 45 , esse quadro se expandiu, passando a albergar correntes que são adeptas a fenômenos diversos, modificando, dessa forma, a direção jurisprudencial, vez que se incluiu na ordem nacional o $\$ 3^{\circ}$ do artigo $5^{\circ}$ da Constituição Federal (BRASIL, 1988), redação na qual assevera que

[...] os tratados e convenções internacionais sobre direitos humanos que forem aprovados, em cada Casa do Congresso Nacional, em dois turnos, por três quintos dos votos dos respectivos membros, serão equivalentes às emendas constitucionais. (BRASIL, 1988, art. 5. grifos do autor)

Com esse novo dispositivo, os tratados ${ }^{10}$, ao adentrarem na ordem jurídica nacional, não mais blasonam força normativa de lei ordinária, vez que, com o intuito de atribuírem direitos humanos à ordem interna, galgarão a envergadura equivalente à norma constitucional, desde que adentrem nesta sob o fulcro do processo legislativo de emenda à Constituição,

10 Segundo o entendimento de José Francisco Rezek, tratado "[...] compreenderia todo acordo formal concluído entre os sujeitos de direito internacional público, com o intuito de produzir efeitos jurídicos" (REZEK, 2000, p. 14). 
para valerem sob tais conformações no sistema jurídico-constitucional brasileiro. ${ }^{11}$

Dessa forma, é necessário se assinalar que antes mesmo do advento do dispositivo supra exortado, os tratados já detinham, por parte de algumas decisões do STF, força de norma constitucional, como se pôde depreender da decisão do Ministro Paulo Sepúlveda Pertence. ${ }^{12}$ Especialmente na decisão da medida cautelar na ADI 1675-1, em que se abalizou que os tratados internacionais sobre direitos humanos celebrados pelo Brasil, anteriores à promulgação da Constituição de 1988, se alinhariam à estatura e força de dispositivo constitucional.

Assim, na atual circunstância, face ao dispositivo que trouxe a possibilidade de se equiparar à norma constitucional os tratados de direitos humanos, convém esclarecermos o que compreenderia esta equiparação. Destaque-se que, para a conformação de uma verdadeira norma de índole constitucional há a necessidade da combinação de duas facetas que se complementam. A primeira delas tem relevância quanto ao conteúdo veiculado pela norma em questão, refletindo decisões fundamentais sobre a

11 Flávia Piovesan (2005, p. 67-81, p. 69) vai ainda mais longe, entende que a partir desta Emenda passam a sobressair na doutrina nacional quatro correntes interpretativa a respeito da hierarquia dos tratados internacionais de direitos humanos, quais sejam: “[...] a) a hierarquia supraconstitucional destes tratados; b) a hierarquia constitucional; c) a hierarquia infraconstitucional, mas supralegal; e d) a paridade hierárquica entre tratado e lei federal". Por deter este assunto grandes deblaterações, posto que não detém corrente que conseguiu, por completo sua pacificação, nem mesmo em âmbito do Tribunal Constitucional, neste estudo se defenderá a hierarquia constitucional dos tratados internacionais que versem sobre direitos humanos, principalmente, por este se basear num tratado específico que concerne aos direitos humanos fundamentais das pessoas com deficiência."

12 Do escólio de José Afonso da Silva (2008, p. 179) depreende-se que "[...] parte da doutrina - que tinha meu apoio - sustentava que essa incorporação se dava já com qualidade de norma constitucional; outra entendia que assim não era, porque esses acordos internacionais não eram aprovados com o mesmo quorum exigido para a formação de normas constitucionais [...]". Em tempo, neste atual cenário, com a inserção do $\S 3^{\circ}$ ao artigo $5^{\circ}$ da $\mathrm{CF}$, não há mais empecilho a se conclamar estes tratados de direitos humanos como detentores de fundamentalidade material de norma constitucional, vez que se prédetermina sua aprovação com quórum de Emenda à Constituição para adentrarem na ordem jurídica interna. 
estrutura do Estado e da sociedade, bem como diretamente ligados à pessoa, dignamente considerada. No caso em questão por serem normas que decorrem dos tratados em que o Brasil é signatário (BRASIL, 1988, art. $5^{\circ}, \S 2^{\circ}$ ), confirma-se a existência dessa faceta material. Já a constitucionalidade formal vincula-se à forma de positivação dessas normas na hierarquia do ordenamento.

Ora, os tratados de direitos humanos por consubstanciarem matéria com essencialidade constitucional só pelo fato de serem introduzidos em nossa ordem interna são considerados materialmente constitucionais, mas para completarem a outra faceta - de verdadeira norma constitucional elevando-se sua colocação na ordem interna - dependem de aprovação com quorum qualificado, como se dá com as Emendas à Constituição, galgando também a constitucionalidade formal.

Cumpridas todas as formalidades emendárias que proporcionam aos tratados internacionais força de norma constitucional dever-se-á proceder à sua aplicabilidade, para que, além de terem mera eficácia jurídica, galguem eficácia social e realizem-se as determinações de seu texto. Assim, quanto às pessoas com deficiência já se configurou tal possibilidade, necessitando, ainda, de regulamentação o teor deste tratado. Passa-se, neste diapasão, a análise da possibilidade de utilização do mandado de injunção em substituição à omissão legislativa em seu cumprimento, que tornaram inviáveis os direitos humanos fundamentais consagrados em seu bojo.

\section{Mandado de Injunção: instrumento contra as omissões legis- lativas na regulamentação do teor dos tratados internacionais sobre direitos humanos das pessoas com deficiência}

O Texto Constitucional de 1988, além de fomentar uma inegável gama de direitos e garantias das mais variadas camadas da sociedade, trouxe um novel dispositivo, o mandado de injunção, com a prerrogativa de tornar exequível os direitos fundamentais pendentes de complementação (regulamentação) legislativa. 
Tal instrumento tem origem no direito inglês, porém, devido ao fato de em tal direito vigorar o commow law, nossa Carta em nada se aproxima de sua injunction. Segundo Orlando Soares (SOARES, 1990, p. 130) o writ do Direito anglo-saxão "[...] se inspira no princípio segundo o qual judge made law, ou seja, que admite a participação judiciária, na elaboração legislativa, nos casos de omissão da lei, ou com base em precedente (case)".

Ademais, nos estritos termos gramaticais (semânticos) a injunção seria simplesmente uma ordem precisa e formal, contudo, por vir escoltada do termo mandado, enseja um comunicado ou anúncio, um mandar fazer e não somente um deixar por fazer, ou melhor, "[...] um suprimento judicial, consubstanciado numa ordem formal, impositiva, de natureza mandamental" (SOARES, 1990, p. 132).

Nem lá, nem cá, essa garantia chega tão longe como no commow law, nem se espera tão amesquinhada como uma interpretação meramente literal. Pretende-se com o mandado de injunção a construção de alicerces para a mais ampla e irrestrita proteção dos preceitos consignados na Constituição, sob uma plataforma principiológica que lhe dê sustentação e fundamentação, ante sua supremacia.

Nessa aferição, cabe recordar que o Mandado de Injunção surgiu concomitantemente ao período de redemocratização do Estado brasileiro, quando se ponderava que os remédios constitucionais, então existentes, não enfrentavam de maneira corajosa a inconstitucionalidade de um não fazer, numa escusa injustificada que pairava como um diletantismo leviano dos Poderes de Estado.

Assim, diante da omissão injustificada do Poder Legiferante em cumprir seu mister, eis que abrolha o Mandado de injunção como uma nova garantia constitucional na Carta de 1988 com o intuito de ver suprimida, por meio do Poder Judiciário, a ausência de norma regulamentadora que permitisse o exercício dos direitos assegurados naquela, atribuindo às pessoas um mecanismo apto a outorgar aplicabilidade às normas constitucionais, ou melhor, é uma ação constitucional que tem a finalidade precípua de tutelar os direitos fundamentais consignados no Texto Constitucional. 
Entretanto, não se quer com a definição exarada linhas acima afirmar que o Poder Judiciário - nesses termos representado por seu órgão de cúpula, o STF - usurpando as funções que lhes são constitucionalmente atribuídas, irá legislar atipicamente, mas que tendo o dever precípuo de guarda da Constituição (BRASIL, 1988, art. 102) detém a prerrogativa de fomentar as condições normativas para o amplo exercício, in casu, dos direitos das pessoas com deficiência, vez que a omissão legislativa em regulamentar determinada norma constitucional afeta diretamente o próprio conteúdo normativo da Carta.

Diversamente, há aqueles, como Luis Roberto Barroso (2006, p. 117) - posicionamento no qual não acolhemos -, que entende que "[...] o objeto do mandado de injunção é o suprimento da norma faltante na solução do caso concreto". Ora, ao se defender esse pensamento estar-seá proporcionando maior vazão à valorização dos interesses (particulares) em jogo e não à reverência afeita à supremacia constitucional e, especialmente, aos valores tutelados em seu bojo.

Repita-se, a omissão não torna inócua a realização de norma constitucional pelo Judiciário, vez que por via do mandado de injunção poderse-á estabelecer condições normativas para o exercício de direitos fundamentais, especialmente das pessoas com deficiência. Condições essas fulcradas em uma moldura constitucional principiológica, já que conjectura-se por imprópria quando "[...] uma garantia constitucional não outorga direito algum aos governados, senão que só imponha a obrigação de legislar, o que implica que se não tem vontade de fazê-lo o preceito constitucional resta derrogado de fato". (MENDES, 2007, p. 28), e esse não é o objetivo do sistema constitucional hodierno.

Nesse sentido, é o entendimento de Celso Lafer, afirmando que o Texto Constitucional " [...] caracteriza-se pela substantiva incorporação de princípios gerais, voltados para indicar um sentido de direção que a Constituição busca imprimir à sociedade [...]" (LAFER, 2005, p. 13), e consequentemente aos institutos consignados em seu cerne, como o mandado de injunção.

Ademais, ocupa posição privilegiada no Texto Constitucional, localizado no artigo $5^{\circ}$, inciso LXXI, do Capítulo I, Título II, dentro dos 
direitos e garantias fundamentais, visto tratar-se de norma protegida nos termos do artigo $60, \S 4^{\circ}$, de forma intangível e ainda, de acordo com artigo $5^{\circ}, \S 1^{\circ}$, possui aplicação imediata ${ }^{13}$.

Ora, a letra da lei, de forma clara, aponta o objeto do instituto, não ensejando maiores dúvidas, "[...] os valores constitucionais inscritos no inciso da injunção existem por si mesmos e não graças ao desejo, necessidade ou escolha do legislador ou do juiz" (MENDES, 2007, p. 28). A função que deve desempenhar tal garantia não se dará pelo julgador ou legislador ordinário, seu papel adviria do próprio sistema jurídico-constitucional.

A questão que deteria uma maior dificuldade refere-se ao alcance deste instituto, vez que, um interprete menos avisado poderia suscitar a ideia de lacuna técnica prevista na Lei de Introdução do Código Civil. Caso, em que o operador do direito, diante da ausência de norma decide por meio da integração, conforme artigos $4^{\circ}$ e $5^{\circ}$ da referida lei. Porém, o mandado de injunção, apesar de se justificar pela ausência de norma, possui outra função.

A rigor, não se podem confundir as tarefas de complementação - regulamentação faltante - e de aplicação do direito - mecanismos que aproximam o texto da lei da realidade do caso concreto. Sob esta objeção convém nos reportarmos ao asseverado por Rachel Bruno Anastácio (2003, p. 48-49) ao afirmar que:

\footnotetext{
13 Apesar de haver uma corrente minoritária que entende que este dispositivo, quanto à aplicabilidade procedimental, ainda depende de regulamentação. Parece-nos contraditório que a garantia constitucional criada com a finalidade de resguardar os direitos fundamentais pendentes de regulamentação tivesse, ela mesma, que ser regulamentada. Em tempo, convém asseverarmos que o STF já se manifestou sobre esse assunto, determinando que o procedimento a tornar possível a prática processual desse instituto será o mesmo do Mandado de Segurança. Depreende-se assim do voto do Ministro Presidente do MI 1073/DF: "O Tribunal, por unanimidade, conheceu da Questão de Ordem que lhe submeteu o Sr. Ministro-Relator e a decidiu no sentido de reconhecer a natureza mandamental do Mandado de Injunção e a auto aplicabilidade do art. 5º inciso LXXI, da Constituição, adotando-se, no que couber, o procedimento do Mandado de Segurança, e com os efeitos enunciados no voto do Sr. Ministro-Relator." (BRASIL, 1990).
} 
Em se tratando especificamente do mandado de injunção, foi este criado para resolver o problema de aplicabilidade de normas constitucionais de eficácia limitada, também conhecidas, conforme já se teve oportunidade de verificar, como normas não auto-aplicáveis. Não há, efetivamente, uma situação de lacuna técnica tal como estudado nas preliminares lições de direito, já que esta encontra saída no próprio sistema (analogia, costumes e princípios gerais do direito).

Com efeito, pode-se elucubrar que a saída mais ponderada decorreria de uma análise hermenêutico-interpretativa da Carta, confrontada com seus limites e sua superioridade e a necessidade precípua de defendê-la, fundada nos princípios constitucionais que norteiam o aparelhamento jurídico-democrático.

Nesse ínterim, o instituto constitucional é que será levado à apreciação do Judiciário ante ao direito inviabilizado, pois dessa forma, os dispositivos constitucionais pendentes de complementação regulamentar tornam inócua a realização dos direitos com galhardia constitucional, convertendo-se o Mandado de Injunção como o completo acesso aos direitos fundamentais ainda pendentes de contornos normativos que lhes dê forma.

Ademais, a omissão legislativa se apresenta não apenas quando o legislador não cumpre o seu dever, mas também, quando não o desempenha satisfatoriamente. Afinal, a Constituição deve ser interpretada de modo amplo, perquirindo seu fundamento base de assegurar e possibilitar o desenvolvimento dos direitos fundamentais presentes em seu cerne.

Contrapondo-se a este pensamento, pode-se afirmar que tal atividade atingiria o princípio constitucional da separação dos poderes. Contudo, constata-se que o STF não estaria usurpando a função de Poder Legislativo, na verdade, estaria auxiliando este Poder a desempenhar de forma plena e perspicaz seu papel perante a sociedade.

Ora, muitas vezes, o ser humano é tomado por sentimentos de vaidade que impedem o efetivo desenvolvimento dos preceitos constitucionais. Assim, essa faculdade do STF agir existiria unicamente no caso do legislador, por não ter desempenhado sua atividade plenamente, que dei- 
xasse a Constituição Federal em uma situação de inferioridade, exercendo uma função meramente simbólica. Dentre as possibilidades de interpretação quanto ao resultado da decisão de Mandado de Injunção, pode-se discorrer uma linha crescente na atividade do STF que vai desde uma total inocuidade - existente desde o berço da promulgação da Constituição - chegando à beira de descomedimento, como se poderá vislumbrar das últimas decisões proferidas pela Corte em sede injuncional. ${ }^{14}$

A primeira interpretação, a não-concretista assemelha o Mandado de injunção à ação direta de inconstitucionalidade por omissão, conforme se nota da Ementa do MI 107-3/DF:

14 Necessário se registrar que desde o advento da Constituição Federal de 1988 pode-se aferir diversos posicionamentos do STF em sede de mandado de injunção, teorias estas que se passa a discorrer. A primeira delas, a teoria não-concretista foi seguida durante anos de forma majoritária pelo Supremo Tribunal Federal, determinando que caberia ao Poder Judiciário somente o reconhecimento formal da inércia legislativa e, a consequente comunicação ao Poder Legislativo da inexistência da lei e da necessidade de edição da norma regulamentadora. Para essa teoria a adoção de uma medida diferente atingiria a separação dos Poderes. Por ter predominado de modo majoritário no Supremo Tribunal Federal durante longo tempo, o mandado de injunção não produziu efeitos. Uma segunda, mais dilatada e abrangente, processa um novo entendimento, suplantando a mera cientificação do órgão responsável, teoria essa que se divide em diversas modalidades, demonstrando a própria evolução do no entendimento dos ministros. Pela teoria concretista geral, a qual foi recentemente adotada em decisões proferidas pelo Excelso Tribunal como, por exemplo, MI 670, 708 e 712, estabelecem que, frente à ausência de norma regulamentadora, incumbe ao Poder Judiciário o suprimento da lacuna. $\mathrm{O}$ que nos permite dizer que por meio de uma sentença o Poder Judiciário colocaria fim a omissão, pois, além de tornar exequível o exercício do direito ao impetrante do Mandado de Injunção, desdobraria seus efeitos a todos, ou seja, efeito erga omnes. Já a Teoria concretista individual, que também está sendo utilizada pelo Supremo Tribunal Federal, citando de forma exemplificativa o MI 721, assevera que diante de uma norma faltante, cabe ao Poder Judiciário a criação da regulamentação para o caso específico, gerando apenas, efeitos inter partes. Por fim a teoria concretista intermediária, a qual simboliza a junção da teoria não-concretista com a teoria concretista individual, preconiza que frente à falta de norma regulamentadora compete ao Poder Judiciário comunicar ao órgão competente para a elaboração da norma regulamentadora necessária ao exercício do direito constitucional, fixando para isso um prazo e caso esse lapso de tempo expire sem a elaboração da norma, ficaria o Poder Judiciário autorizado a suprir a falta de normatização, possibilitando o exercício dos direitos assegurados constitucionalmente. 
Mandado de Injunção. Questão de ordem sobre sua auto-aplicabilidade, ou não. - em face dos textos da constituição federal relativos ao mandado de injunção, é ele ação outorgada ao titular de direito, garantia ou prerrogativa a que alude o artigo $5^{\circ}$, LXXI, dos quais o exercício esta inviabilizado pela falta de norma regulamentadora, e ação que visa a obter do Poder Judiciário a declaração de inconstitucionalidade dessa omissão se estiver caracterizada a mora em regulamentar por parte do poder, órgão, entidade ou autoridade de que ela dependa, com a finalidade de que se lhe de ciência dessa declaração, para que adote as providências necessárias, a semelhança do que ocorre com a ação direta de inconstitucionalidade por omissão, e de que se determine, se se tratar de direito constitucional oponível contra o Estado, a suspensão dos processos judiciais ou administrativos de que possa advir para o impetrante dano que não ocorreria se não houvesse a omissão inconstitucional. - assim fixada a natureza desse mandado, e ele, no âmbito da competência desta corte - que esta devidamente definida pelo artigo 102, i, 'q' -, auto-executável, uma vez que, para ser utilizado, não depende de norma jurídica que o regulamente, inclusive quanto ao procedimento, aplicável que lhe e analogicamente o procedimento do mandado de segurança, no que couber. Questão de ordem que se resolve no sentido da auto-aplicabilidade do mandado de injunção, nos termos do voto do Relator. (BRASIL, 1990, s./p.).

Pela ementa colacionada, observa-se que o objeto do mandado de injunção ensejaria sua equiparação à ação de inconstitucionalidade por omissão, o que tornou tal teoria deveras perniciosa e amesquinhada, vez que o mandado de injunção não se identifica com qualquer instrumento posto na Carta, ele é único e depende de um delineamento próprio que dê um conteúdo condizente com seus objetivos. Por esse entendimento induz-se o Poder Judiciário a, simplesmente, dar ciência ao Poder Legislativo sobre a falta da norma regulamentadora.

Pelo segundo entendimento considera-se que após cientificar-se o órgão competente, dever-se-á fixar prazo para que seja suprida a omissão. E, se ainda, assim, ele permanecer em silêncio, ao Poder Judiciário caberia a concessão do direito pleiteado, da mesma forma que o anterior, este também não reflete o conformado pela injunção, apesar de já se vis- 
lumbrar o início do afastamento da posição de ineficácia que permeava o instituto. Nesse sentido, convém mencionar o MI 232-15, em que claramente observa-se que o STF, revendo seu posicionamento, atribuiu prazo para que a carência da norma fosse suprida.

E, por fim, cabe mencionar a possibilidade de reconhecida a mora pelo Mandado de Injunção, ao Judiciário seria permitido atribuir o direito ao exercício da norma regulamentadora. Em consideração ao argumento de preservação e respeito à separação de poderes, o Mandado de Injunção, até mesmo em virtude de seus legitimados, apresenta de forma ampla maior eficácia que a ação de inconstitucionalidade por omissão. A ela cabe a elaboração da norma faltante. Ao Mandado de Injunção, cabe, sobretudo, assegurar a viabilidade de um direito não exercido pela carência de norma regulamentadora, vez que, repita-se, o fim basilar deste instituto é tutelar os direitos fundamentais que se tornaram irrealizáveis em virtude da norma faltante. Nesse sentido, exara-se o entendimento de Luís Roberto Barroso (2009, p. 273), que afirma que "[...] a Corte parece se render aos apelos da doutrina dominante, conferindo efetividade ao mandado de injunção [...]".

Contudo, equivoca-se o citado autor, vez que não foi o caso de dar efetividade ao instrumento de mandado de injunção, não será bem esse o intuito, mas sim por meio dele tornar viável os preceitos constitucionais pendentes de realização, outorgando-lhe outro embasamento além daqueles que vislumbrou nos primeiros anos de seu estabelecimento.

Nessa vereda, em que pese, anteriormente, tão só sobejar ao STF a possibilidade de remeter a ciência ao órgão competente, que foi outorga-

15 Ementa: Mandado de injunção - Legitimidade ativa da requerente para impetrar mandado de injunção por falta de regulamentação do disposto no $§ 7$ do artigo 195 da Constituição Federal. - Ocorrência, no caso, em face do disposto no artigo 59 do ADCT, de mora, por parte do Congresso, na regulamentação daquele preceito constitucional. Mandado de injunção conhecido, em parte, e, nessa parte, deferido para declarar-se o estado de mora em que se encontra o Congresso Nacional, a fim de que, no prazo de seis meses, adote ele as providencias legislativas que se impõem para o cumprimento da obrigação de legislar decorrente do artigo $195, \S 7^{\circ}$, da Constituição, sob pena de, vencido esse prazo sem que essa obrigação se cumpra, passar o requerente a gozar da imunidade requerida. (BRASIL, 1992). 
do constitucionalmente à realização do direito completando a norma faltante, este Tribunal novou em seu posicionamento, atuando como verdadeiro guardião mor do Texto Constitucional, abrindo um novo horizonte em suas decisões.

\subsection{Novo Horizonte das Decisões do Supremo Tribunal Federal}

Como se pode perceber em linhas acima, por longa data o Supremo Tribunal Federal fez uso, nas decisões de ação de mandado de injunção, de uma teoria que não refletia em nada os anseios de sua consignação no Texto Constitucional, era a não-concretista, ou seja, estabeleceu-se que ao Poder Judiciário caberia, apenas, o reconhecimento formal da inércia legislativa e a respectiva comunicação ao órgão competente para a elaboração da norma regulamentadora necessária ao exercício do direito constitucional inviabilizado, de modo a preservar a separação de Poderes fixada pelo artigo $2^{\circ}$ do Texto Constitucional.

Contudo, no fim de 2006 e vigorosamente em 2007, o Excelso Tribunal mudou sua visão quanto aos efeitos da decisão exarada em Mandado de injunção. Não se sabe ao certo se isso se deve ao descrédito e desapontamento dos juristas pela adoção da teoria não-concretista ou se foi consequência das alterações dos ministros.

Essa posição se torna clara nos dizeres do Ministro Marco Aurélio, nos autos do Mandado de Injunção n. 721 quando coloca que:

É tempo de se perceber a frustração gerada pela postura inicial, transformando o mandado de injunção em ação simplesmente declaratória do ato omissivo, resultando em algo que não interessa, em si, no tocante à prestação jurisdicional, tal como consta no inciso LXXI do art. $5^{\circ}$ da Constituição Federal, ao cidadão.

Ora, vislumbrou-se que é perfeitamente apto o Judiciário a realizar os direitos que frivolamente os Poderes competentes se furtaram de satisfazer, vez que "[...] o principal fator de legitimação da atuação do Judiciário é a omissão do outro Poder, que tinha como efeito a paralisação da 
eficácia de normas constitucionais". Assim, “[...] o provimento de mandado de injunção serve justamente para evitar a eternização dessa situação de desrespeito à força normativa da Constituição" (BARROSO, 2009, p. 274-275, grifo do autor).

Com efeito, apesar do mandado de injunção ter como função indelével evitar que os preceitos constitucionais quedem-se irrealizáveis ad eternum, o Judiciário, através do STF não adquire legitimidade em razão essencialmente da omissão do Poder competente para tanto, mas especialmente, por caber a este a defesa incondicional dos valores e mandamentos constitucionais.

Assim, desde o ano de 2006, além do marco da revisão da decisão do mandado de injunção, elucubrou-se, também, uma verdadeira reforma hermenêutico-interpretativa na Corte Constitucional. Entretanto, o grande salto ocorreu, verdadeiramente, em 2007 com o julgamento de três mandados de injunção que tinham por objeto o direito de greve dos servidores públicos civis. Diante dos preceitos afixados no artigo 37, VII da Lei Maior - direito ao exercício da greve condicionado à edição de lei específica - não havia qualquer regulamentação que permitisse a execução dessa garantia.

Todavia, adentrando a tal dispositivo de forma interpretativa, tomando-o como detentor de eficácia contida, pode-se concluir que os servidores públicos poderiam se valer da Lei n. 7.783/89 de forma analógica. Porém, o guardião da Carta, por entender que se tratava de norma de eficácia limitada, não permitia o exercício da greve enquanto não formulada lei pertinente ao tema.

Nas decisões do MI 670, 708 e 712 adotou-se a teoria concretista, ou seja, o Poder Judiciário além do suprimento da lacuna, também estenderia os efeitos a todos (erga omnes).

Enquanto a adoção desse entendimento servia de acalanto para alguns, vozes alardeavam que essa postura por parte do Supremo Tribunal Federal concederia ao Judiciário o exercício da atividade legislativa, o que feriria a Separação dos Poderes. 
Entretanto, o presente estudo pretende sustentar pensamento oposto. Atribuindo ao Judiciário o dever de evitar lesão a direitos e exercer função defensiva e não legislativa propriamente, de modo a não subsistir argumentos contra a Separação de Poderes.

Registre-se ainda que, por todo o abordado, há que se ressaltar que apesar de se ter passado de um verdadeiro ostracismo para um protagonismo excessivo esse posicionamento do STF ainda não possui alicerces sólidos, vez que tem gerado grandiosas deblaterações sobre o desrespeito à separação de Poderes, principalmente porque dentre os votos dos ministros não houve uma fundamentação de pudesse sustentar uma efetiva defesa, resguardo ou guarida aos valores, preceitos e objetivos consignados na Carta. Pelo contrário, vislumbram-se mais uma vez uma queda de braço em que cresce a soberba, a arrogância e a fatuidade dos membros de nossa Corte Constitucional, para ver quem pode mais na corda bam$b a$ dos Poderes. Avanços, certamente houveram, principalmente por se ter deixado a conveniente posição de conforto, para se traçar novos horizontes; a largada foi dada almejando-se que os premiados sejam os cidadãos - principalmente os grupos marginalizados da sociedade - e a democracia sob o ápice da Constituição Federal.

\subsection{A Possibilidade do Mandado de Injunção Viabilizar o Teor dos Tratados Internacionais sobre Direitos Humanos das Pessoas com Deficiência}

Indelevelmente os tratados internacionais que albergam direitos humanos ensejam uma abertura do Texto Constitucional ao recepcioná-los, vez que adentram na ordem jurídica interna dotados de uma constitucionalidade material, conforme se pode extrair do $\S 2^{\circ}$ do artigo $5^{\circ}$. Ademais, com a reforma trazida pela Emenda n. $45 / 04$, que inseriu o $\S 3^{\circ}$ ao artigo $5^{\circ}$, veio confirmar o exposto no parágrafo antecedente, bem como responder às constantes discussões sobre a natureza equiparada à norma constitucional aos tratados que subscrevem direitos humanos.

Sob esse auspício é o entendimento de Flávia Piovesan (2005, p. 72 ), pois " $[\ldots]$ os tratados de direitos humanos formalmente constitucio- 
nais são equipados às emendas à Constituição, isto é, passam a integrar o texto constitucional".

Nesse diapasão, seguindo-se a assertiva exarada anteriormente, convém elucubrar-se que pelo fato dos tratados, depois de realizados os tramites da aprovação nas Casas do Congresso, passam a fazer parte do rol de normas constitucionais detendo aplicabilidade imediata, como se pode depreender do $\S 1^{\circ}$ do artigo $5^{\circ}$ da Constituição Federal.

Com efeito, por conduzirem as mesmas possibilidades de relações, o direito internacional e o direito interno figuram-se na mesma direção, ajustam-se à finalidade primacial e singular de ambos, a tutela do ser humano (CANÇADO TRINDADE, 2000).

Inicialmente, deve-se asseverar que, em conformidade com o escólio lapidado por Antônio Augusto Cançado Trindade (2000), os mandamentos contidos nos tratados que versem sobre direitos humanos conjecturam-se numa íntima vinculação do Estado signatário como um todo, ou seja, equivocam-se as determinações que afirmam comportar tão só aos governos isoladamente, vez que os tratados se conformam em elucubrações de organismos internacionais ou mesmo outros Estados também soberanos.

Ora, dada a importância que se depreende desses acordos internacionais, pois valorados umbilicalmente à pessoa humana, comportam um dever de abrangência entre os direitos da humanidade, considerando que em sede constitucional igualmente encerram direitos humanos fundamentais, seu reduto reflete em todos os Poderes, órgãos e Instituições do Estado. Nesse sentido, é a afirmação de José Joaquim Gomes Canotilho (2003, p. 221):

No que tange ao governo e à administração, incumbe-lhes um importante papel na tarefa de concretização dos direitos fundamentais, tendo em vista que, no exercício de sua competência planificadora, regulamentar, fornecedora de prestações, os órgãos da administração e do governo desenvolvem tarefas de realização de direitos fundamentais. 
Em contrapartida, ao Judiciário, esse mesmo dever revela-se no comprometimento teleoconstitucional que, além de interpretar os preceitos constitucionais conjecturadores de direitos fundamentais em sua atuação, mantém-se conectado à tutela da pessoa humana, agindo no controle dos demais Poderes de Estado, tendo o condão de defender o elucubrado no Texto Constitucional.

O Judiciário por deter a função de guarda de flancos de toda a $m u$ ralha conformada pela Constituição detém alguns instrumentos que tem a função de garantir a proteção dos direitos fundamentais que consagra, como o mandado de injunção, que conforme mencionado, enseja-se diante da irrealizabilidade de determinado direito ante a falta de norma que o regulamente. Ou seja, “[...] revela-se o mandado de injunção como verdadeiro instrumento de realização do princípio da aplicabilidade imediata das normas definidoras dos direitos e garantias fundamentais [...]" (PIOVESAN, 2003, p. 142).

Ora, constatando-se que já existe um tratado internacional sobre direitos humanos aprovado pelo Congresso Nacional com status de Emenda Constitucional: trata-se da Convenção sobre os Direitos das Pessoas com Deficiência e seu Protocolo Facultativo, ${ }^{16}$ é perfeitamente cabível a utilização do mandado de injunção com essa finalidade. Vislumbramo-la quando o Judiciário, utilizando-se de princípios constitucionais, pudesse viabilizar seu conteúdo, outorgando às pessoas com deficiência a plena fruição dos direitos fundamentais internacionalmente traçados.

Sobre tal Convenção, pode-se destacar alguns dispositivos que expressamente afirmam a necessidade de regulamentação, conforme se colaciona, (BRASIL, 1988, s./p.):

"Artigo 4. Obrigações Gerais:

1. Estados Membros devem assegurar a plena realização de todos os direitos humanos e liberdades fundamentais para todos os indivíduos com deficiência, sem discriminação de qualquer tipo em razão de deficiência. Para esse fim, os Estados Membros devem:

${ }^{16}$ Aprovados na forma do artigo $5^{\circ}, \S 3^{\circ}$, da Constituição Federal, pelo Decreto Legislativo n. 186, de 9 de julho de 2008. 
(a) Adotar medidas legislativas, administrativas e outras para a implementação dos direitos reconhecido nesta presente Convenção,

(b) Tomar todas as medidas apropriadas, incluindo as legislativas, para emendar, anular ou invalidar qualquer lei, regulamentação, costumes e práticas que constituam descriminação contra as pessoas com deficiência;" (grifos do autor).

Registre-se que essa Convenção, que trata das pessoas com deficiência, além de conjecturar uma definição mais precisa sobre esse grupo de pessoas, também expandiu o rol de direitos consignados a estes, dessa forma, se se elucubrar o teor dos tratados internacionais, especificamente nesse caso, de direitos humanos das pessoas com deficiência como normas com força equivalentes às emendas constitucionais - desde que adentrem à ordem interna por processo legislativo regulamente determinado à conformação de emendas à Constituição - enseja-se para sua efetiva aplicabilidade sua regulamentação, tornando-se o Mandado de Injunção um lídimo instrumento para que se realize a defesa dos valores escudados na Carta diante da inércia do Poder competente.

Portanto, segundo o entendimento de Zeno Veloso (2000), o mandado de injunção proporciona dar uma ilimitada liberdade de ação ao Legislador sobre este assunto, dando a mais ampla imunidade, além pô-lo incólume de qualquer forma de opressão ou censura, é ensejar às maiorias parlamentares o apanágio irrestrito de determinar o momento e a necessidade de aplicação dos mandamentos constitucionais que carecem de regulamentação. Continuando, afirma que:

A fiscalização jurisdicional é possível e admissível se o Legislativo se omite quando tinha de atender a uma exigência específica de editar normas sobre dada matéria constitucional, ficando demonstrado que o momento, a oportunidade para que tal ocorresse já passou. Neste caso, a omissão chega às raias da desídia, sendo a apatia viciosa e reprovável (VELOSO, 2000, p. 252).

Com efeito, pelo fato do mandado de injunção ter como "[...] principal finalidade conferir imediata viabilidade ao exercício de direitos, liberdades e prerrogativas constitucionais, obstado em virtude de ausência 
de regulamentação [...]" (PIOVESAN, 2003, p. 141) e, principalmente, por esta omissão legislativa referir-se, especificamente, a um grupo de pessoas que sofreram um processo histórico de exclusão e descriminação, no afã de se conformar ao artigo $1^{\circ}$, inciso III da Carta, bem como se adaptar às modificações introduzidas pelo $\S 3^{\circ}$ do artigo $5^{\circ}$. Assim, é perfeitamente cabível sua consignação desta garantia aos direitos humanos fundamentais das pessoas com deficiência vislumbrando-se a mais ampla tutela de seus direitos, para que estes não se quedem tão só como meras declarações, como se vislumbrou outrora.

\section{Conclusões}

Pelo presente estudo teve-se o intuito de analisar a importância dos direitos humanos fundamentais, não no que se refere propriamente a sua previsão, mas sim, a sua proteção e alcance, de modo a acompanhar a desenvoltura obtida dentro do tema pessoa com deficiência, especialmente quanto a avanços trazidos pelos acordos internacionais no qual o Brasil é signatário.

Ocorre que, em que pese a crescente evolução que se observou no percorrer da história ocidental a respeito da positivação de direitos humanos fundamentais, constatou-se que a pessoa humana somente passou a ser objeto de consideração, mais precisamente, após a segunda metade do século passado, em que passados os horrores da segunda guerra, iniciouse um movimento em direção ao ser humano dignamente considerado, gravado expressamente na Declaração de Direitos do Homem de 1948. Todavia, apesar do avanço que essa trouxe, ainda assim, havia grupos que se quedaram historicamente inertes dessa consideração, como as pessoas com deficiência, como se até mesmo lhes estivesse ausente a própria humanidade. Situação que perdurou e vivencia-se até hoje, em todo o mundo.

Em âmbito nacional, a pessoa com deficiência só galgou efetiva tutela constitucional com a Carta de 1988, além de consignar como objetivos do Estado a busca de uma sociedade livre, justa e solidária, cunhada na erradicação das desigualdades sociais e da marginalização de grupos historicamente excluídos. 
Ademais, após a EC n. 45/04, outorgou-se aos diplomas internacionais, que tratassem de direitos humanos, índole de norma constitucional. Curiosamente, o primeiro instrumento internacional que adentrou na ordem interna foi a Convenção sobre os Direitos das Pessoas com Deficiência. Diploma esse que tutelando direitos humanos e sendo ratificado na ordem interna sob os parâmetros de emenda à Constituição teria a mesma envergadura de norma constitucional.

Entretanto, deparamo-nos com a necessidade de regulamentação de alguns de seus dispositivos, e ante a inércia dos Poderes vocacionados a tal realização, cumpre ao Poder Judiciário, valendo em sua decisão de uma fundamentação embasada nos princípios constantes da Constituição, fulcrado em sua supremacia nos objetivos e valores que o Estado se comprometeu defender, conformar a mais ampla tutela dos direitos das pessoas com deficiência.

A Corte Suprema brasileira, como autêntica representante do Poder Judiciário, conjectura-se como guarda de flancos de toda a estrutura conformada pela Constituição, vale-se do mandado de injunção como instrumento que tem o condão de garantir a defesa e a proteção dos direitos fundamentais que consigna, ante da irrealizabilidade dos direitos das pessoas com deficiência em razão da ausência de norma que os torne plenamente exercitáveis.

Com efeito, constata-se que o problema concernente à viabilidade dos direitos das pessoas com deficiência suplanta a simples falta de regulamentação. Pois, em verdade, não há como regulamentar o respeito, a tolerância e a responsabilidade dos membros pertencentes à sociedade, muito menos fazer com que os Poderes de Estado cumpram à risca o dever que constitucionalmente se comprometeram.

Necessita-se, prementemente, de uma mudança de mentalidade ante a cultura historicamente enraizada em nossa sociedade altamente capitalista que valoriza apenas aqueles situados nos lindes da normalidade. Depreende-se, assim que a impossibilidade das pessoas com deficiência exercerem seus direitos decorre mais de um obstáculo social e de falta de comprometimento em realizar o pacto constitucional - e agora, inter- 
nacional -, do que, diretamente, pela sua ausência de normatização do Estado.

\section{Referências}

ALVIM, Eduardo Arruda. Apontamentos sobre o processo das ações coletivas. In: MAZZEI, Rodrigo Reis; DIAS, Rita (Coords.). Processo Civil Coletivo. São Paulo: Quartier Latin, 2005.

ANASTÁCIO, Rachel Bruno. Mandado de Injunção: em busca da Efetividade da Constituição. Rio de Janeiro: Lúmen Júris, 2003.

ARAUJO, Luiz Alberto David. A Defesa Coletiva das Pessoas Portadoras de Deficiência. In: MAZZEI, Rodrigo Reis; DIAS, Rita (Coord.). Processo Civil Coletivo. São Paulo: Quartier Latin, 2005.

. A proteção constitucional das pessoas portadoras de deficiência. Brasília: CORDE, 2001.

BARROSO, Luiz Roberto. O direito constitucional e a efetividade de suas normas. Limites e possibilidade da Constituição brasileira. 9. ed. Rio de Janeiro: Renovar, 2009.

. O controle de constitucionalidade no direito brasileiro. São Paulo: Saraiva, 2006.

. Interpretação e Aplicação da Constituição. 6. ed. São Paulo: Saraiva, 2004.

BARROSO, Luiz Roberto; NUNES JÚNIOR, Vidal Serrano. Curso de Direito Constitucional. 12. ed. São Paulo: Saraiva, 2008.

BOBBIO, Norberto. A Era dos direitos. Rio de Janeiro: Campus, 1992. BONAVIDES, Paulo. Curso de direito constitucional, 15. ed. São Paulo: Malheiros, 2004.

BRASIL. Constituição Federal do Brasil. 1988. Disponível em: $<$ http:// www.planalto.gov.br/ccivil_03/constituicao/constitui\%C3\%A7ao.htm>. Acesso em: 16 maio 2011. 
. MI 107 QO / DF DISTRITO FEDERAL. Tribunal Pleno. Rel. Ministro Moreira Alves. Julgamento: 23 nov 1989. Diário da Justiça da União. Brasília, DF, 21 set. 1990. Disponível em: < http://www.stf. jus.br/portal/jurisprudencia/listarJurisprudencia.asp?s1=mandado $\% 20$ de\%20injunção(107\%20\%20.NUME.\%20OU\%20107\%20\%20. ACMS.)\&base=baseAcordaos>. Acesso em: 3 out. 2009.

. MI 232/RJ RIO DE JANEIRO. Tribunal Pleno. Rel. Ministro Moreira Alves. Julgamento: 2 fev 1991. Diário da Justiça da União. Brasília, DF, 27 mar. 1992. Disponível em: < http://www.stf.jus.br/portal/ jurisprudencia/listarJurisprudencia.asp?s1=MI(232.NUME. $\% 200 U \% 20$ 232.ACMS.)\&base=baseAcordaos $>$. Acesso em: 5 out. 2009.

. Habeas Corpus n. 82.424, do Pleno do Tribunal de Justiça do Estado do Rio Grande do Sul. Rel. Min. Marco Aurélio Mello. Julgado em 17 set. 2003. Diário da Justiça, Brasília, 19 mar. 2004. Disponível em: <http://www.stf.jus.br/portal/jurisprudencia/listarJurisprudencia. asp?s1=HC.SCLA.+E+82424.NUME.\&base=baseAcordaos $>$. Acesso em: 2 maio 2009.

. Supremo Tribunal Federal. Informativo 498. Rel. Ministro Celso de Mello. Julgamento: 14 mar. 2008. Disponível em: $<$ http://www. stf.jus.br/portal/informativo/verInformativo.asp?s1=Tratados\&numero=4 98\&pagina $=22 \&$ base $=I N F O>$. Acesso em: 10 jan. 2011.

BYDLOWSKI, Lizia. Tormento dos diferentes em nome da raça. In: Revista Veja. São Paulo: Abril. 3 set. 1997. Disponível em: <http://veja. abril.com.br/030997/p_036.html>. Acesso em: 30 ago. 2010.

CANÇADO TRINDADE, Antônio Augusto. Tratado de direito internacional dos direitos humanos. 2. ed. Porto Alegre: Sérgio Antonio Fabris, 2003. $1 \mathrm{v}$.

. A proteção internacional dos direitos humanos e o Brasil.

Brasília: Universidade de Brasília, 2000.

CANOTILHO, José Joaquim Gomes. Direito constitucional. 4. ed. Coimbra: Almedina, 1993.

. Curso constitucional e teoria da Constituição. Coimbra: Almedina, 1999. 
CANOTILHO, José Joaquim Gomes; MOREIRA, Vital. Constituição da República Portuguesa anotada. 4. ed. Coimbra: Coimbra; 1. ed. São Paulo: Revista dos Tribunais, 2007. 1 v.

CHINCHILLA HERRERA, Túlio Eli. Que son y cuales son los derechos fundamentales. Santa Fé de Bogotá: Temis, 1999.

DANIEL, Roberto Francisco. Ser Pessoa: A base ontológica do direito. In: ARAUJO, Luiz Alberto David (Coord.). Efetivando direitos constitucionais. Bauru: EDITE, 2003. p. 551-564.

FERREIRA FILHO, Manoel Gonçalves. Curso de direito constitucional. 28. ed. São Paulo: Saraiva, 2002.

FIGUEIREDO, Marcelo. Mandado de injunção e inconstitucionalidade por omissão. São Paulo: Revista dos Tribunais, 1991.

FREIRE JÚNIOR, Américo Bedê. Pontos Nervosos da Tutela Coletiva: Legitimação, Competência e Coisa Julgada. In: MAZZEI, Rodrigo Reis; DIAS, Rita (Coord.). Processo civil coletivo. São Paulo: Quartier Latin, 2005.

HERRERA FLORES, Joaquin. A (re)invenção dos direitos humanos. Trad. Carlos Roberto Diogo Garcia, Antonio Henrique Graciano Suxberger e Jefferson Aparecido Dias. Florianópolis: Fundação Boiteux, 2009.

LAFER, Celso. A internacionalização dos direitos humanos:

Constituição, racismo e relações internacionais. Baurueri/SP: Monoele, 2005.

LOUREIRO, Lair da Silva. Mandado de segurança e Mandado de Injunção: jurisprudência do órgão especial do tribunal de justiça do Estado de São Paulo de 1998/1995. São Paulo: Saraiva, 1996.

MACHADO, Carlos Augusto Alcântra. Mandado de Injunção: um instrumento de efetividade da Constituição. São Paulo: Atlas, 1999.

MANCUSO, Rodolfo de Camargo. Interesses difusos: conceito e legitimação para agir. São Paulo: Revista dos Tribunais, 2004. 
MARTINEZ PULJATE, Antonio Luis. La garantia del contenido esencial de los derechos fundamentales. Madrid: Centro de Estúdios Constuticionales, 1997.

MAZZILI, Hugo Nigro. A defesa dos interesses difusos em juízo. 3. ed. São Paulo: Revista dos Tribunais, 1991.

MENDES, Sérgio da Silva. Hermenêutica da criação... e dos esquecimentos: O Holzwege do mandado de injunção. In: Revista Eletrônica de Direito do Estado. Salvador, n. 9, jan./fev./mar., 2007.

Disponível em: $<$ http://www.direitodoestado.com.br/rede.asp $>$. Acesso em: 25 nov. 2010.

MÉXICO. Suprema Corte de Justicia de la Nación. El derecho a la información. Série Debates, Pleno, n. 26, 2000.

OLIVEIRA, Francisco Antônio de. Mandado de Injunção: da inconstitucionalidade por omissão, enfoques trabalhistas, jurisprudência. São Paulo: Revista dos Tribunais, 2004.

PACHECO, José da Silva. O mandado de segurança e outras ações constitucionais típicas. 4. ed. São Paulo: Revista dos Tribunais, 2002.

PÉREZ LUÑO, Antonio-Enrique. Los derechos fundamentales. 6. ed. Madrid: Tecnos, 1995.

PFEIFFER, Roberto Augusto Castellanos. Mandado de Injunção. São Paulo: Atlas, 1999.

PIOVESAN, Flávia. Reforma do Judiciário e Direitos Humanos. In: TAVARES, André Ramos; LORA ALARCÓN, Pietro de Jesus (Coord.). Reforma do Judiciário: Analisada e comentada. São Paulo: Método, 2005. p. 67-81.

. Proteção Judicial contra omissões legislativas. Ação direta de inconstitucionalidade por omissão e mandado de injunção. 2. ed. São Paulo: Revista dos Tribunais, 2003.

. A proteção dos direitos humanos no sistema constitucional brasileiro. In: Revista da Procuradoria do Estado de São Paulo. v. 5152, jan/dez. 1999, p. 92. 
REZEK, José Francisco. Direito internacional público. 8. ed. São Paulo: Saraiva, 2000.

RULLI NETO, Antonio. Direitos do portador de necessidades especiais. São Paulo: Fiúza, 2002.

SILVA, José Afonso da. Comentário contextual à Constituição. 5. ed. São Paulo: Malheiros, 2008.

. Curso de direito constitucional positivo. 16. ed. São Paulo: Malheiros, 1999.

SIDOU, J. M. Othon. Habeas corpus, mandado de segurança, mandado de injunção, habeas data, ação popular: as garantias ativas dos direitos coletivos. Rio de Janeiro: Forense, 1998.

SOARES, Orlando. Comentários à Constituição da República Federativa do Brasil. Rio de Janeiro: Forense, 1990.

UNESCO. Déclaration de principes sur la tolérance. Disponível em: $<$ http://www.unesco.org/cpp/fr/declarations/tolerance.htm $>$. Acesso em: 31 ago. 2010.

VELOSO, Carlos. Os tratados na jurisprudência do Supremo Tribunal Federal. Revista de Informação Legislativa, Brasília. Ano 41, n. 162, abr.jul., 2004.

VELLOSO, Zeno. Controle jurisdicional de constitucionalidade. Belo Horizonte: Del Rey, 2000.

WERNECK, Claudia. Sociedade Inclusiva. Quem cabe no seu Todos? Rio de Janeiro: WVA, 1999.

. Muito prazer, eu existo: um livro sobre as pessoas com síndrome de Down. 2. ed. Rio de Janeiro: WVA, 1993. 